\title{
Impact of Oil Dependence on the Nigeria's Economic Growth
}

\author{
Hasan Güngör ${ }^{1}$ Abubakar M. Nyako ${ }^{2}$ \\ ${ }^{1}$ Department of Economics, Eastern Mediterranean University North Cyprus, via Mersin 10 Turkey \\ ${ }^{2}$ Department of Economics, Eastern Mediterranean University North Cyprus, via Mersin 10 Turkey
}

\begin{abstract}
This study aims to capture the effect of oil dependence on the Nigeria's economic growth from 1973 to 2013. Applying the ARDL bounds testing co-integration procedure, the oil rents ratio to GDP was used as a proxy for oil dependence and a significant negative correlation was discovered between oil dependence and GDP per capita, which was robust to the specification employed. The export sector value added had an insignificant negative correlation with GDP per capita in the long run; this is due to the high level of dependence on oil. Thus validating the presence of Dutch disease in the Nigerian economy. The study suggested the expansion of Foreign Direct Investment and sterilization of oil rents overseas by fostering Incentives so as to reduce the oil price shocks and the negative effects of crude oil prompted capital inflow in the Nigeria's economy.
\end{abstract}

Keywords: Oil dependence, Economic growth, Natural resources.

Jel Code: $F 43-C 22-Q 43$

\section{Introduction}

Crude oil is widely believed to instigate overall development and stir economic growth for economies that are fortunate enough to be possessed with this resource, this belief is not based on evidence because recent studies in this area has revealed that oil deprived economies grow relatively faster than oil dominated economies. In fact, the consequence of oil rich economies tends to contradict this whole perception. High level of corruption, violence \& rent seeking culture, poverty at the highest level, slow growth rates and inequality are some of the socio economic weakness that defines oil rich economies.

The Nigerian economy has experienced a persistent economic growth over a decade now. As of 2014 the annual real GDP increase from $6.3 \%$ to around 7\% in 2015 [1]. Mining, agriculture and crude oil extraction are the oriented primary production. The oil and gas reports for over $65 \%$ of gross real outputs and over $80 \%$ of foreign exchange revenue in 2013. About $4.14 \%$ government revenues and foreign exchange was accounted for manufacturing and other construction sectors [2]. Even the non-oil sector which has not been given much attention in the past decade has experienced a tremendous growth and these are the service sector, housing \& construction and real estate [3]. One sector that grew so fast in the past decade is the services sector, which has an increasing share of GDP from $25 \%$ in the year 2000 to $57 \%$ in 2015 [4]. The present driver of growth in the Nigeria's economy is the non-oil sector, with the agriculture and manufacturing sector respectively contributing about $21 \%$ and $9 \%$ while the services sector generated around $57 \%$ [1]. Thus the economy is more servicesoriented and also diversifying, particularly through real estate, telecommunication \& information sector and wholesale \& retail trade. The Nigeria's 2015 expectation was for moderate growth rate of 5\%, this is due to slow recovery of the global economy, global financial developments and oil-price volatility. However, there was a rapid fall in fiscal revenues because of the low oil price but the overall effect was quite less on the non-oil sectors. The services sector is however expected to continue to be the driver of growth. An adjustment policy was implemented by the government so as to shore up non-oil income and tighten government expenditure to compensate for diminishing oil rents.

\section{Review of Literature}

According to the mainstream economists, a country should produce and export based on their comparative advantage. The theory of comparative advantage suggests higher economic benefit of one country than the other thereby producing at a lower cost. Other countries will also benefit if they produce a product of which they have advantage on, hence accepting the advantage cost of the other trading country. This is what mainstream beliefs in for specialization, trade and international division of labor. This is why some countries produce agricultural products while others produce industrial goods [5]. On the other hand structural economists argue many claims of mainstream economists. The idea of less dependence on resources and diversification is what the structural economists view lies on. [6,7] studied the relationship between natural resource abundance and economic growth by using a cross country data sample from 1971 to 1989 . According to their analysis, economies with significant natural resource export tended to have lower growth rate, even after controlling for the important variables that triggers economic growth such as trade policy, initial per capita income, investment 
rate, government efficiency and others. The negative relationship still holds. [8] studied the impact of oil rent on the economy of the oil exporting African nations. He tested his claim by using panel data for 47 oil exporting countries from 1970-2000. He also included 13 non-oil exporting countries. The finding shows that there was an evidence of resource curse in the oil exporting countries. In addition oil exporting African countries are significantly affected including their exchange rates. Dutch disease syndrome could not illustrate the resource curse in these regions which includes Africa. Conclusively oil rents failed to promote growth. [9] [10] studied empirical trade structure and economic growth relationship. The study focused on export concentration, natural resource endowment and intra industry trade. Therefore they tested for the robustness of the relationship among proxies, estimation methods and by using controlled variables. Hence, they constructed a cross sectional and a panel extending from 1975-1999 i.e. 5 year observation. Their studies imply that natural resource abundance has a positive effect on growth meanwhile export concentration impedes growth, despite physical and accumulation of human capital is being controlled.

\section{Data And Analysis}

The data used for this research were obtained from the World Bank (WDI) and United Nations Statistical Database (UNSTAT). The study covers time series from 1973 to 2013. The import sector value added to GDP in US Dollars; The services sector contributions to GDP in US Dollars; The Export sector contributions to GDP in US Dollars are gathered from the UNSTAT. Whereas the share of oil rents in GDP and the Naira/Dollar exchange rate are obtained from WDI.

To test for the stationarity of the variables in the model, Augmented Dickey Fuller (ADF) unit root test is employed so as to know the co-integration order of the series. ARDL bound test will be applied to model the co-integrating relationship among the variables in the long run and in the short run.

\subsection{Model Specification}

For the purpose of this study, a log linear specification is suggested; $\ln G D P=\beta_{0}+\beta_{1} \ln E X P T+\beta_{2} \ln E X C H+\beta_{3} \ln S E R V+\beta_{4} \operatorname{InIMP}+\beta_{5} O I L D E P+u$

Equation above shows the model in an explicit form. $\beta$ is the intercept term.

The variables include;

InGDP - Natural log of real per capita GDP

OILDEP - Oil dependence (ratio of oil rents to GDP)

$\ln E X C H$ - Natural log of real US/Nigerian bilateral exchange rates

$\operatorname{lnSERV}$ - Natural log of services real contribution to GDP.

InIMP - Natural log of imports real contribution to GDP.

lnEXP - Natural log of exports real contribution to GDP.

$U t$ - Random disturbance error term

For this study we will use the Autoregressive Distributed Lag (ARDL) procedure to co-integration recommended by [11] to determine the short run and long run relationships between variables. This methodology is chosen according to certain criterias. First, this approach provides unbiased estimates of the model in the long run and a reliable t-statistics even if some of the explanatory variables are endogenous [12]. However, [13] and [14] explained that an addition of the dynamics may assist in fixing the endogeneity bias. Secondly, according to [11], the ARDL model generates a reliable long run parameter estimates that are normally assymptotic without regarding the integration order i.e. if the variables are mutually integrated, I(0) or I(1). Third, the bounds technique is the most appropriate statistical approach to establish small samples cointegration relation [15] meanwhile the large data samples are collected for validity through the Johansen cointegration techniques. We constructed an ARDL conditional error correction model, explained below:

$\Delta \operatorname{lng}_{\text {g }} \boldsymbol{k}_{t}=\alpha+\sum_{i=0}^{n} \beta_{1 i} \Delta \operatorname{lnexch}_{t-i}+\sum_{i=0}^{n} \beta_{2 i} \Delta$ oildep $_{t-i}+\sum_{i=0}^{n} \beta_{3 i} \Delta \operatorname{lnimp}_{t-i}+\sum_{i=0}^{n} \beta_{4 i} \Delta \operatorname{lnexp}_{t-I}+\sum_{i=0}^{n} \beta_{5 i}$ $\Delta \operatorname{lnserv}_{t-i}+\Phi E C M_{t-1}+\varepsilon_{t t}$

The Equation above shows the ARDL model, $\Phi$ represents the speed of adjustment coefficient, The $E C M$ denotes the error correction mechanism and within a period, it captures the speed at which disequilibrium in lngdpk are corrected. For the model to be correcting, stable and co-integrated, the ECM coefficient in absolute values must be negatively significant and less than one.

According to [16], most economic time series have to be differenced to be static. In fact, many economic variables seem to have trend. Hence, they are non-stationary in most cases. Thus, testing for nonstationarity means checking for the presence of a unit root. Prior to the implementation of the ARDL technique, regressing a non-stationary time series results to misleading inferences [17], therefore all variables must be tested for stationarity. The unit root test is used to verify the integration order and it is an essential requirement for the presence of co-integration [18]. To investigate the existence or absence of unit root in each variable we 
use the Augmented Dickey Fuller test, thereby determining the integration order. We can now specify the long run linkages by choosing the integration order for each variable i.e. I(0) or I(1).

The ADF unit root test widely accepted model specification can be written as:

$\Delta \mathrm{y}_{\mathrm{t}}=\alpha_{1}+\alpha_{2}+\mu \mathrm{y}_{\mathrm{t}-1}+\delta_{1}+\sum_{t-1}^{m} \Delta y_{t-1}+u \mathrm{t}$

Where:

$\alpha_{1}$ - Constant trend or a drift,

$\alpha_{2}$ - Time trend parameter,

$\sum_{t-1}^{m} \Delta y_{t-1}$ - Autoregressive process for lag order

$\Delta Y t$ - The change in variable yt and lag

$\delta$ - The unit root

$u \mathrm{t}$ - White noise error term.

ADF test can be with constant and none or constant and trend the ADF hypothesis can be written as:

$\mathrm{H}_{0}: \delta=0$ (non-stationary)

$\mathrm{H}_{\mathrm{a}}: \delta<0$ (stationary)

For ADF test proper specification of the model we have to confirm if its a pure random walk variable or the variable is a random walk with time trend and drift trend or random walk with drift trend. Then, we can determine the amount of lags to be included in the model.

Table 1: Result for the Unit Root Test

\begin{tabular}{|c|c|c|c|}
\hline Variables & I(0)levels & I(1)first difference & Integration Order \\
\hline Oildepp & Reject $\mathrm{H}_{0}$ & Reject $\mathrm{H}_{0}$ & $\mathrm{I}(0) \quad * * *$ \\
\hline Lngdpk & Cannot reject $\mathrm{H}_{0}$ & Reject $\mathrm{H}_{0}$ & $\mathrm{I}(1) \quad * * *$ \\
\hline Lnexpts & Cannot reject $\mathrm{H}_{0}$ & Reject $\mathrm{H}_{0}$ & $\mathrm{I}(1)$ \\
\hline Lnserv & Cannot reject $\mathrm{H}_{0}$ & Reject H0 & $\mathrm{I}(1)$ \\
\hline Lnexr & Cannot reject $\mathrm{H}_{0}$ & Reject $\mathrm{H}_{0}$ & $\mathrm{I}(1)$ \\
\hline Lnimpts & Cannot reject $\mathrm{H}_{0}$ & Reject $\mathrm{H}_{0}$ & $\mathrm{I}(1)$ \\
\hline
\end{tabular}

From Table 1 it can be seen that all the variables were integrated of order one I (1) except for oil dependence which was integrated of order zero I (0), However this is not a problem because the ARDL model accommodates different integration order of variables as long as when the variable goes through the procedure of bounds testing, the no co-integration null can be rejected.

\section{Bounds Co-integration test}

[11] developed a bounds testing technique which is employed when we are not certain if the variables are of the same order i.e. $\mathrm{I}(0)$ or $\mathrm{I}(1)$ or $\mathrm{I}(2)$. This procedure is used to check the existence of relationship among the variable in the long run and it is in accordance with the F-test and written as follows:

Ho: $\beta_{1}=\beta_{2}=\beta_{3}=\beta_{4}=\beta_{5}=0$

The variables are not co-integrated

Ha: $\beta_{1} \neq \beta_{2} \neq \beta_{3} \neq \beta_{4} \neq \beta_{5} \neq 0$

The variables are co-integrated

We apply the F-test with a non-standard asymptotic distribution when the explanatory variables are $I(d)$ with $0 \leq d \leq 1$ i.e. Two bounds asymptotic critical values are used to determine the co-integration test. The upper bound assumes that all the regressors are $I(1)$, and the lower bound assumes they are $I(0)$. The null is rejected, if the estimated F-statistics lies on the upper plain of the band, showing the presence of co-integration [13]. The null hypothesis will not be rejected, if the estimated F statistics lies under the lower level of the band, indicating the absence of co-integration. However, the assumption would be inconclusive, if the statistics lies within the band.

Table 2: Bounds Testing For Co integration

\begin{tabular}{lll}
\hline \hline Test Statistic & Value & $\mathrm{K}$ \\
\hline \hline F-statistic & 6.360403 & 5 \\
\hline \hline & & \\
Critical Value Bounds & \\
\hline \hline Significance & $\mathrm{I}(0)$ Bound & $\mathrm{I}(1)$ Bound \\
\hline \hline $10 \%$ & 2.75 & 3.79 \\
$5 \%$ & 3.12 & 4.25 \\
$2.5 \%$ & 3.49 & 4.67 \\
$1 \%$ & 3.93 & 5.23 \\
\hline \hline
\end{tabular}


In Table 2 the result shows that all the variables are co-integrated. Therefore the no co-integration null is rejected, as the calculated $6.36 \mathrm{~F}$ statistic is greater than the upper bound critical values. Once we confirm that a long-run co-integration relationship exists. The next stage, the variables were estimated using Schwartz Bayesian criteria to determine the appropriate lags and the criteria chooses 2 lags. Then we estimate the ARDL short run and the long run relationship between the coefficients.

\begin{tabular}{|c|c|c|c|c|}
\hline \multicolumn{5}{|c|}{ Co-integrating Form } \\
\hline Variable & Coefficient & Std. Error & t-Statistic & Prob. \\
\hline D(OILDEP) & 0.001652 & 0.000690 & 2.392441 & 0.0257 \\
\hline D(OILDEP(-1)) & 0.003308 & 0.000755 & 4.382280 & 0.0002 \\
\hline $\mathrm{D}(\operatorname{OILDEP}(-2))$ & 0.001117 & 0.000761 & 1.467106 & 0.1565 \\
\hline $\mathrm{D}(\mathrm{LIMP})$ & 0.029860 & 0.024919 & 1.198298 & 0.2436 \\
\hline $\mathrm{D}(\mathrm{LEXCH})$ & -0.039257 & 0.023907 & -1.642029 & 0.1148 \\
\hline $\mathrm{D}(\mathrm{LEXCH}(-1))$ & -0.010744 & 0.029952 & -0.358692 & 0.7232 \\
\hline $\mathrm{D}(\mathrm{LEXCH}(-2))$ & -0.065872 & 0.023187 & -2.840902 & 0.0095 \\
\hline D(LSERV) & 0.781679 & 0.097822 & 7.990829 & 0.0000 \\
\hline D(LSERV(-1)) & -0.300540 & 0.093802 & -3.203995 & 0.0041 \\
\hline $\mathrm{D}($ LEXP $)$ & -0.039033 & 0.032108 & -1.215678 & 0.2370 \\
\hline D(@TREND()) & -0.017875 & 0.004926 & -3.628550 & 0.0015 \\
\hline CointEq(-1) & -0.498155 & 0.132984 & -3.745988 & 0.0011 \\
\hline
\end{tabular}

Cointeq $=$ LGDPK $-(-0.0083 *$ OILDEP + 0.0599*LIMP + 0.0787*LEXCH + 0.6109*LSERV 0.0784*LEXP -6.5391-0.0359*@TREND )

Long Run Coefficients

\begin{tabular}{lrrrr}
\hline \hline Variable & Coefficient & Std. Error & t-Statistic & Prob. \\
\hline \hline OILDEP & -0.008280 & 0.002424 & -3.416424 & 0.0025 \\
LIMP & 0.059941 & 0.038795 & 1.545079 & 0.1366 \\
LEXCH & 0.078692 & 0.038417 & 2.048381 & 0.0526 \\
LSERV & 0.610935 & 0.091040 & 6.710594 & 0.0000 \\
LEXP & -0.078356 & 0.058700 & -1.334849 & 0.1956 \\
C & -6.539101 & 1.806663 & -3.619436 & 0.0015 \\
@TREND & -0.035883 & 0.009164 & -3.915742 & 0.0007 \\
\hline \hline
\end{tabular}

From Table 3 the exchange rate coefficient is statistically significant at the $10 \%$ level and for the services sector was significant at the $1 \%$ level. The p-values are below 0.05 . Thus, null hypothesis (H0) is rejected. Import and export however were not significant but import had a positive relationship while export was negatively related with the GDP per capita. In addition, the importation implies capital outflow but the effect of the capital outflow is mitigated by the foreign exchange coming from oil, therefore there is no relationship in the long run. Thus import might be endogenous. Nevertheless, the positive relationship of import may also be because of the endogeneity when there is an economic boom or a rise in GDP and thus positive relationship between import and GDP might imply causality running from GDP to imports. However, the export is negative and insignificant; this may be because about $90 \%$ of Nigerian export is crude oil based. This is in line with [19], who also found an insignificant negative relationship between oil export and per capita GDP. It can also be seen that in the long run a negative significant relationship exist between oil dependence (OILDEP) and per capita GDP, this is due to the volatility of terms of trade. This is in accordance with the result obtained by [8] and [6,7]. This implies that a unit standard deviation expansion in Oil rents ratio to GDP (OILDEP) will bring about a reduction in GDP per-capita by 0.008 percentage points in the long run, holding other factors constant and this is at the $1 \%$ level of significance. Service sector has a positive significant relationship with GDP per-capita as a $1 \%$ expansion in services sector leads to about $0.6 \%$ increase in GDP per-capita in the long run, holding other factors constant. The positive significant relationship is due to the indirect industrialization 
were by resources and funds move from the manufacturing, agricultural and the oil sector to the services sector, which gains more spending effect from a boom in oil sector in the long run. Therefore a boom in oil sector strengthens the services sector; therefore in the long run the volatility of the oil prices will have no significant effect on the services sector. The real exchange rates had a positive and significant relationship with real per capita GDP. Ceteris paribus, a one percent increase in real exchange rate brings about 0.07 percent increase in per capita real GDP.

ARDL-ECM-Short Run Dynamics

Table 4.Error Correction

\begin{tabular}{|c|c|c|c|c|}
\hline Variable & Coefficient & Std. Error & $\mathrm{t}$-Statistic & Prob. \\
\hline D(OILDEP) & 0.001459 & 0.000669 & 2.179608 & 0.0403 \\
\hline D(OILDEP(-1)) & 0.004146 & 0.000923 & 4.493972 & 0.0002 \\
\hline D(OILDEP(-2)) & 0.001081 & 0.000779 & 1.387549 & 0.1792 \\
\hline $\mathrm{D}(\mathrm{LEXCH})$ & -0.042262 & 0.022919 & -1.843964 & 0.0787 \\
\hline $\mathrm{D}(\mathrm{LEXCH}(-1))$ & -0.080892 & 0.021883 & -3.696523 & 0.0013 \\
\hline $\mathrm{D}(\mathrm{LEXCH}(-2))$ & -0.056976 & 0.022853 & -2.493164 & 0.0207 \\
\hline D(LSERV) & 0.754143 & 0.093278 & 8.084934 & 0.0000 \\
\hline D(LSERV(-1)) & -0.295606 & 0.096246 & -3.071358 & 0.0056 \\
\hline $\mathrm{C}$ & -3.048246 & 1.274278 & -2.392137 & 0.0257 \\
\hline @TREND & -0.018256 & 0.005123 & -3.563720 & 0.0017 \\
\hline OILDEP(-1) & -0.003970 & 0.001011 & -3.927589 & 0.0007 \\
\hline LIMP(-1) & 0.021958 & 0.021409 & 1.025667 & 0.3162 \\
\hline LEXCH(-1) & 0.045540 & 0.014591 & 3.121121 & 0.0050 \\
\hline $\operatorname{LSERV}(-1)$ & 0.282763 & 0.085597 & 3.303410 & 0.0032 \\
\hline LEXP(-1) & -0.032092 & 0.032652 & -0.982860 & 0.3364 \\
\hline LGDPK(-1) & -0.451382 & 0.116164 & -3.885733 & 0.0008 \\
\hline ECM(-1) & -0.855630 & 0.0036913 & 3.415740 & 0.0025 \\
\hline R-squared & 0.897926 & Mean dependent var & & 0.007291 \\
\hline Adjusted R-squared & 0.828330 & S.D. dependent var & & 0.071493 \\
\hline S.E. of regression & 0.029622 & Akaike info criterion & & -3.905052 \\
\hline Sum squared resid & 0.019304 & Schwarz criterion & & -3.215542 \\
\hline Log likelihood & 90.19598 & Hannan-Quinn criter & & -3.659729 \\
\hline F-statistic & 12.90202 & Durbin-Watson stat & & 2.484095 \\
\hline Prob(F-statistic) & 0.000000 & & & \\
\hline
\end{tabular}

From table 4 it can be seen that the model has a good fit as the R-squared value is 0.89 , which implies $89 \%$ of variability in GDP is explained by the variables. A significant positive relationship was discovered between oil dependence and per capita GDP in the short run. The coefficient on services was however ambiguous. The exchange rate coefficient is negatively related with GDP in the short run. The ECM has a negative and a significant coefficient, which implies that $85 \%$ deviation in $L G D P K$ from its equilibrium level (co-integrating values) is fixed within a period.

\section{Conclusion}

The paper investigates the relationship between oil dependence and per capita GDP for Nigeria by applying the ARDL bounds testing approach to co-integration and using annual data time series from 19732013. Conclusively, oil dependence presents a negative significant effect on the economy and this effect is transmitted from the exchange rate to the balance of payments, down to the manufacturing sector. The manufacturing sector remains impeded because the government cannot sustain a single productive development strategy due to the high level of dependence on volatile oil price, making diversification more challenging to implement. Import and export however were not significant but import had a positive relationship while export was negatively related with the GDP per capita, this is due to the complete reliance on oil revenue. In addition, the importation implies capital outflow but the effect of the capital outflow is lessened by the foreign exchange coming from oil, therefore there is no relationship in the long run. Thus import might be endogenous. Nevertheless, the positive relationship of import may be because of the endogeneity when there is an economic boom or a rise in GDP and thus positive relationship between import and GDP might imply causality running from GDP to imports. Based on the empirical result, the services sector equally has a significant and positive 
relationship with the growth of the economy and this is due to the indirect industrialization were by productive resources and funds move from the manufacturing and agricultural sector to the services sector which gains more spending effect from a boom in oil sector in the long run. A boom in oil sector strengthens the services sector. As such it will gain the effect of spending that is prompted by the boom in the oil sector because of the substitutability in imports. Domestic demand will increase by the spending effect although it would lead to a reduction in the agricultural goods production due to the crowding out effect.

\section{References}

[1]. African Economic Outlook, (AEO). African Economic Outlook Annual Report. West Africa, Nigeria African Economic Outlook. (2015).

[2]. National Planning Commission (NPC).Annual Performance of the Nigerian Economy 2010. Abuja: National Planning Commission. (2014).

[3]. World Bank .Nigeria Economic Report Washington, DC: World Bank (2014), (No. 1).

[4]. Banque Nationale de Paris (BNP), A dynamic and diversifying economy. Paris: BNP. (2015).

[5]. O'Toole, G. Politics Latin America. Harlow: Pearson Education Limited. (2007).

[6]. Sachs, Jeffrey D., and Andrew M. Warner. Natural resource abundance and economic growth. No. w5398. National Bureau of Economic Research, 1995.

[7]. Sachs, Jeffrey D., and Andrew M. Warner. "Sources of slow growth in African economies." Journal of African economies 6, no. 3 (1997): 335-376.

[8]. Olomola Philip Akanni. Oil wealth and economic growth in oil exporting African countries. Vol. 170. Kenya, Nairobi: African Economic Research Consortium, 2007.

[9]. Al-Marhubi, F. Export diversification and growth. Applied Economics Letters, (2000), vol. 7, issue 9, pages 559-562.

[10]. Lederman, Daniel, and William Maloney. "Trade structure and growth. World Bank Policy Research Working Paper N $3025 . "$ The World Bank, Washington, DC, USA (2003).

[11]. Pesaran, M. Hashem, Yongcheol Shin, and Richard J. Smith. "Bounds testing approaches to the analysis of level relationships." Journal of applied econometrics 16, no. 3 (2001): 289-326.

[12]. Harris, Richard, and Robert Sollis. Applied time series modelling and forecasting. Wiley, 2003.

[13]. Pesaran, Mohammad Hashem, and Bahram Pesaran. Working with Microfit 4.0: interactive econometric analysis;[Windows version]. Oxford University Press, 1997.

[14]. Inder, Brett. "Estimating long-run relationships in economics: a comparison of different approaches." Journal of econometrics 57, no. 1-3 (1993): 53-68.

[15]. Ghatak, Subrata, and Jalal U. Siddiki. "The use of the ARDL approach in estimating virtual exchange rates in India." Journal of Applied statistics 28, no. 5 (2001): 573-583.

[16]. Nelson, Charles R., and Charles R. Plosser. "Trends and random walks in macroeconmic time series: some evidence and implications." Journal of monetary economics 10, no. 2 (1982): 139-162.

[17]. Libanio, Gilberto A. "Unit roots in macroeconomic time series: theory, implications, and evidence." Nova Economia 15, no. 3 (2005): 145-176.

[18]. Glynn, John, Nelson Perera, and Reetu Verma. "Unit root tests and structural breaks: a survey with applications." (2007).

[19]. Ovikuomagbe, O., and Udoakobong, E.E. Export Growth and Poverty Reduction in Nigeria, IOSR Journal of Humanities and Social Science. (IOSR-JHSS), (2013). Vol.16. 